\title{
Health education training needs of educators at Makapanstad schools in the North West province
}

\author{
MD Peu, PhD \\ Department of Nursing Science University of Pretoria \\ L Napoles, B Sc Dietetics, MPH \\ Department of Human Nutrition University of Pretoria \\ F Wenhold, PhD \\ Department of Human Nutrition University of Pretoria \\ K Mostert-Wentzel, M Phys T, MBA \\ Department of Physiotherapy University of Pretoria
}

N Seane, B Rad Diagnostic, B (Hons) in Radiotherapy,

Department of Radiography University of Pretoria

\section{Kev words}

health education needs, educators, university support, health promotion in schools

\section{Corresnondence address}

Department of Nursing Science P.O.BOX 667

School of Healthcare Sciences

University of Pretoria

Pretoria

0001

Tel.: (012) 354-2133

Cell: +27825344245

Email:mpeu@medic.up.ac.za

\begin{abstract}
Curationis 33 (1): 33-41
Purpose: The purpose of this study was to explore and describe the health education needs of educators at health promoting schools in Makapanstad in North West Province.

Methodology: Qualitative, exploratory and descriptive paradigm was conducted. The population consisted of educators, at Makapanstad schools, who were directly involved with learners. The participants were purposively selected. Focus group interviews were conducted to collect relevant data from the participants. Tesch data analysis process was used to reach the findings of the research.

Findings: The following categories were identified and theoretically confirmed: The need for the support by the University for the training of educators; The need for the University's acknowledgement of educators' responsibilities; The need for basic knowledge of health promotion; Common health needs of learners; and indirect health problems.
\end{abstract}

Recommendation: It was recommended that a health education package be developed to assist in empowering leamers in Makapanstad schools.

\section{Introduction and background}

The South African School Health Policy and Implementation Guidelines states that school health services should form part of primary health care. This requires integration of health services for school-going children, both within the health sector, and the services and programmes of other sectors. The policy further states that school health services should be located within the broader Health Promoting Schools' Initiative (South Africa, Department of Health, 2003:9).

The World Health Organization (WHO) framework, on which the Health Promoting 
Schools' (HPS) Initiative is based, outlines health education as one of the key elements to achieving health-promoting school status. South African educators should incorporate health education into the school curriculum and become actively involved in activities that promote health in the school (South Africa, Department of Health, 2003:11). However, in this policy, it is assumed that educators are both motivated and adequately equipped to teach and promote health. The policy identifies the following health needs of school-aged children (South Africa, Department of Health, 2003:7-9):

- Poverty and environment;

- Poor nutritional status;

- Sexual activity, human immunodeficiency virus/acquired immunodeficiency syndrome (HIV/

Aids) and reproductive health;

- Trauma, violence and mental health, substance abuse and risk-taking behaviour; and

- Hearing, vision and speech impairment (South Africa, Department of Health, 2003:6-9).

According to the Policy Guidelines for Youth and Adolescents' Health (South Africa, Department of Health, 2001:11), children should be informed about and supported in the use of basic knowledge regarding child health and nutrition. This study was conducted in line with this policy.

A multidisciplinary team of lecturers from the School of Healthcare Sciences of the University of Pretoria working in Makapanstad (North West Province) in 2004 sensitized learners, educators and community to the advantages of a HPS. A needs assessment appraisal (using " The Index" as developed by the Medical Research Council) was then conducted at the four Makapanstad schools Thipe, Mankala, Mekwa-Maseding and Tau-Sebele that participated in this Health Promoting Schools' Project. The data collected from this appraisal were analysed and interpreted using quantitative methods (Needs assessment report, 2004). The many concerns raised contributed to this study. Educators from the four schools expressed that there are no programmes focusing on sexuality education including regular HIV and AIDS programme. It was also empha- sised that there is a need for health education programmes (Needs assessment 2004). It was against this background that the Community Development and Research Committee of the University of Pretoria's School of Healthcare Sciences sought to investigate the readiness of educators at Makapanstad schools to address the needs raised in the policy.

\section{Problem statement}

Educators reported that they were not well equipped to teach and promote health. According to the educators, their only exposure to health education had been during their initial training and they had not received any subsequent in-service training (Needs assessment report, 2004). For educators to be able to provide health education and promote health in their schools, it is essential that they receive relevant training. The research question 'What are the health education training needs of educators at Makapanstad schools?' served as guide in the course of the study.

\section{Purpose of the study}

The purpose of this study was to investigate the health education training needs of educators in Makapanstad schools with the aim of developing a relevant health education programme for these educators. The areas of emphasis of the study were guided by the needs identified in the South African School Health Policy and Implementation Guidelines (South Africa, Department of Health, 2003:6-9).

\section{Objectives of the study}

The objective of the study was to explore and describe the health education training needs of educators at Makapanstad schools.

\section{Definition of concepts}

Health promotion is defined by O'Donnel (1987) in Edelman and Mandle (2002:16) as the science and art of helping people to change their lifestyles to move toward a state of optimal health. Lundy and Janes (2001:289) add that health promotion is an organised action or effort that enhances, supports or promotes the wellbeing of individuals, families, groups, communities or societies.
Health education is a process of assisting individuals, acting separately or collectively, to make informed decisions on matters affecting the health of individuals, families and communities (Edelman \& Mandle, 2002:249).

Community needs assessment is the process of evaluating the health needs, including the nutritional status, of the community, determining what the community's health and nutritional needs are, and identifying where those needs are not being met (Boyle, $2003: 414$ ).

Health status refers to the condition of a population or individual's health, including estimates of quality of life, and physical and psychosocial functioning (Boyle, 2003:414).

Nutritional status is defined as the condition of a population or individual as affected by the intake and utilisation of nutrients and non-nutrients (Boyle, 2003:414).

\section{Research methodology}

Qualitative methods and techniques were used to collect data from selected participants working at schools in Makapanstad.

\section{Research design}

An exploratory and descriptive qualitative research design was used. A descriptive study was conducted to describe the health education needs of educators that will be needed to design health education programme services for educators and University members and to allocate resources efficiently (Katzenellenbogen, Joubert \& Karim, 1997:66). In addition to this, De Vos et al. (2002:109) state that descriptive studies present a picture of the specific details of a situation.

\section{Research population and sampling}

The population of this study consisted of all educators in Makapanstad. Sampling criteria stipulated the inclusion of educators who had been working in Makapanstad for a year or longer. The reason for selecting these educators was their experience in working with the learners of the selected community.

Participants were purposively selected because they possessed the relevant 
information required for this study. To ensure a heterogeneous sample, representatives from each school, as well as from different post levels, were included.

\section{Data collection}

Data were obtained from the selected Makapanstad educators by means of focus group interviews. Four focus groups were conducted during the research project. These interviews were scheduled at times that suited the participants in the study. A focus group interview allows participants to share their thoughts during discussions (Brink, 1999:159). Permission was obtained from the participants to use a tape recorder to record the discussions. Field notes as well as observational notes were kept to support the data collected. The broad introductory question 'What are the health education training needs of educators at Makapanstad schools?' was asked at the interviews. A maximum of eight participants were included per focus group.

\section{Ethical considerations}

Permission to conduct the research was obtained from the district office of the education department and concerned authorities. A full explanation of the purpose of the research was given to participants. Ethical principles were adhered to and participants assured that they would be protected from harm or injury. If participants wanted to withdraw from the study, their right to do so was respected. Respect for human dignity includes the right to self-determination and the right to full participation. The participants were therefore given a copy of the consent form (Polit \& Hungler, 1997:134).

\section{Data analysis}

Data were qualitatively analysed employing qualitative coding methods. The Tesch approach, incorporating eight steps, was followed during data analysis.

First, the data were analysed in the language in which the interviews were conducted. The researcher read all the transcripts carefully to obtain a sense of the whole. Thoughts were written down as they occurred. The topics were abbreviated as codes, and the codes written on the appropriate side of the transcript. The appropriate descriptive wording for topics was identified and turned into categories. A final decision was made on the abbreviation for each category, and the codes were alphabetised. Data that belonged to each category were assembled and the results compared (Creswell, 2003:192; De Vos et al., 2001:345).

\section{Trustworthiness}

Trustworthiness in qualitative research was applied with positive results. To establish the trustworthiness of the study, the following four factors were considered: credibility, confirmability, dependability and transferability (Polit \& Hungler, 1997). These four factors concur with Guba's (1981:75-91) classical model for measuring trustworthiness in qualitative data: truth value (or credibility), neutrality (or confirmability), consistency (or dependability), and applicability (or transferability).Credibility was achieved through prolonged engagement and persistent observation by the researchers (Polit \& Hungler, 1997:305). In this study, comparison was made between data collected from individual interviews and focus group discussions to ensure triangulation. Interviews were held on more than one occasion and with different individuals for triangulation. Triangulation of investigators was employed in the research to guarantee a diversity of approaches toward conducting the interviews and analysing the collected data. Furthermore, member checking was conducted.

The researchers provided sufficient descriptive data to make transferability judgements possible by potential appliers (Lincoln \& Guba, 1985:316).

\section{Discussion of the results and literature control}

The sample of the study comprised of 28 participants. Four individual interviews were also conducted with the principals and/or heads of departments of the four schools. The 28 participants in the focus groups consisted of $21 \mathrm{fe}$ male and 7 male educators from the four schools.

The researcher and co-coder agreed on the categories, subcategories, and themes identified in the transcripts. The categories and subcategories are tabulated (refer to Table 1).

\section{Category 1: The need for support by the university for the training of educators}

The subcategories that emerged from this category were formal training and parental intuition. These were supported by quotes from the participants.

\section{Formal training}

The participants expressed a lack of knowledge about health matters. This was expressed as follows:

"Right now I cannot say I am equipped to promote the health needs of learners". "We don't know anything regarding health". "We don't know anything about the diseases and conditions of our learners". "We need to be trained, especially about diseases that are common in our learners".

The participants expressed the need for training because they felt they had inadequate information regarding health matters, particularly in terms of how to promote health. Leurs, Bessems, Schaalma and De Vries (2007:66) state that school can play an important role in the health promotion of children. These authors mention that, because health promotion is a planned activity, stakeholders should be involved in the process of training and empowering educators and learners on their own health.

\section{Parental intuition}

The participants expressed the importance of their own parental intuition. This was expressed as follows:

"As a parent I cannot say I don't have any knowledge". "I am not trained in health issues but I have children at home, so I must be able to take care of the learners as well".

Parental intuition is important because educators are advocates for their learners. They are not trained in health issues, but assist learners when the need arises. Parental intuition can assist educators to shape their fears regarding what may happen to learners (Meyers, 2007). If educators believe that they have the power, they could be of great help to learners in a school environ- 
Table 1: Educators' health education needs: categories and subcatergories identified

\begin{tabular}{|c|c|c|}
\hline \multicolumn{2}{|c|}{ CATEGORIES } & SUBCATEGORIES \\
\hline 1. & $\begin{array}{l}\text { The need for the support of } \\
\text { the University for the training } \\
\text { of educators }\end{array}$ & $\begin{array}{ll}\text { - } & \text { Formal training } \\
\text { - } & \text { Parental intuition }\end{array}$ \\
\hline 2. & $\begin{array}{l}\text { The need for the University's } \\
\text { acknowledgement of educa- } \\
\text { tors' responsibility }\end{array}$ & $\begin{array}{l}\text { - } \quad \text { Sole responsibility of educators } \\
\text { - } \quad \text { Joint responsibility of educators }\end{array}$ \\
\hline 3. & $\begin{array}{l}\text { The need for basic knowledge } \\
\text { of health promotion }\end{array}$ & $\begin{array}{ll}- & \text { Diet and nutrition } \\
\text { - } & \text { Exercise }\end{array}$ \\
\hline 4. & $\begin{array}{l}\text { Common health needs of } \\
\text { learners }\end{array}$ & $\begin{array}{ll}\text { - } & \text { Teenage pregnancy } \\
\text { - } & \text { Family planning } \\
\text { - } & \text { HIV/Aids } \\
\text { - } & \text { STDs } \\
& \text { Unique needs of special learn- } \\
\text { ers }\end{array}$ \\
\hline & Indirect health problems & $\begin{array}{ll}\text { - } & \text { Poverty } \\
\text { - } & \text { Poor family structure } \\
\text { - } & \text { Lack of resources } \\
\text { - } & \text { Need for full health team }\end{array}$ \\
\hline
\end{tabular}

ment.

\section{Category 2: The need for the university's acknowledgement of educator's responsibility}

The subcategories identified in this category were the sole and joint responsibilities of educators.

\section{Sole responsibility of educators}

The participants stated that:

"I think we as teachers should make time within our busy schedule to talk to learners about heath issues". "I am not trained to do health education but as a parent I think I have that obligation to talk informally to students about health".

"We need to be trained to be better equipped to approach subjects of life, health and sexuality, and also be helped to assess if we are successful".

\section{Joint responsibility of educators}

The participants emphasised the following:

"Actually I think the function of health education and meeting health needs of learners should be ajoint effort with health professionals". "Although the health promotion needs will be our re- sponsibility, we do need a school nurse and an occupational therapist". responsibility regarding learners in a school environment. The participants emphasised that educators have responsibility regarding the physical environment in which learners are during school hours. A healthy school environment should be encouraged by educators in all schools (Stanhope \& Lancaster, 2000:922). If a healthy environment is encouraged, the question is to what extent should learners take control of their own environment. It is practical that educators involve learners in cleaning the environment, as an unhealthy environment may hamper learning. In support of the above discussion, the Department for Education and Employment (England, 1998:6) adds that educators should ensure the health and safety of everyone in the school environment and should act like any reasonable parent would.

\section{Catergory 3: The need for basic knowledge of health promotion}

The subcategories diet and nutrition,
Educators have both a sole and joint exercise and hygiene were identified in this category.

\section{Diet and nutrition}

The participants expressed the following problems associated with nutrition: "Pupils stay without food for the whole day at school". "Many children have stomach problems. I think this is because of junk food they eat, not a well balanced diet"."

The importance of good nutrition in school-age children has been emphasised in many publications over the years, internationally (Drake, Maier, Jukes, Patrikios, Bundy, Gardner \& Dolan,. 2002) and also in South Africa (Wenhold, Kruger \& Muelhof, 2008:442-78). The Research Council of the United States of America (USA) echoed these sentiments in the statement: "Without adequate nutrition, no country can be expected to achieve the national vigor essential for continued development, and economic, social and political stability" (De Haan, 1996:161)

Sufficient consumption of high-quality proteins, vitamins, minerals and energy has been identified as being crucial to the growth of school children. "The school age period is one of steady growth and children attempt to master physical skills and they expend energy in organized sports and games" (Pipes \& Trahms, 1993:144). In South African a growing number of children are faced with multiple problems of malnutrition. These include the entire range of problems that can occur when intakes of nutrients or energy are insufficient, excessive, or simply imbalanced (Steyn, Bradshaw, Norman, Joubert, Schneider, \& Steyn, 2006). Undernourishment may have serious consequences for the school-age child. The child may become easily fatigued, unable to sustain prolonged physical effort or unable to participate fully in learning experiences. Risk of infection is greater in undernourished children and a child may therefore frequently be absent from school (Pipes \& Trahms, 1993:144).

Nutrition education during school years is as important as nutrition itself. Dozens of studies have documented the negative effects of malnourishment on children's intellectual development. "Educating the parents and teachers 
about nutrition provides the knowledge base needed to reduce risk of nutrition related health problems" (Unusan \& Sanlier, 2007:861).

The Directorate: Nutrition in the $\mathrm{Na}$ tional Department of Health has heeded the call for improved nutrition with the development of the integrated nutrition programme. "The nutrition situation is exacerbated by a lack of nutritional information and knowledge; added to these are undesirable dietary habits and nutrition-related practices, attitudes, perceptions and socio-cultural influences that could adversely affect nutritional status. To attain good health and nutritional status, people need sufficient knowledge and skills to grow, purchase, process, prepare, eat and feed their families a variety of foods in the right quantities and combinations " (South Africa, Department of Health, 2003:6-9). (Available: http// www.doh.gov.za/programs/nutritionf.html).

\section{Exercise}

The participants expressed the need for basic knowledge regarding exerciserelated health problems, as follows:

"Teachers need to be taught how to help children who develop health problems during athletics training".

"Teachers need to be empowered as far as health is concerned". "We need to be taught on how to handle children who suffer from asthma".

Sufficient exercise is essential to health. Exercise that makes use of many muscles equally is the best kind. According to De Haan (1996:36), the following health benefits are associated with regular exercise:

- Circulation is sped up, increasing blood supply to the heart, lungs and muscles, as well as the removal of waste from the body.

- Respiration is deeper, more oxygen is taken by the lungs and increased amounts of carbon dioxide are exhaled.

- Exercise leads to a feeling of relaxation and contentment.

However, in asthmatic individuals, exercise, especially vigorous exercise, causes the narrowing of the airways, and asthma during or after exercise is most likely to be a practical problem in children and may interfere with games at school (Rees \& Kanabar, 2000:16).

Lack of exercise, again, contributes to the problem of overweight and obese children that is currently receiving much attention. "Worldwide, the prevalence of overweight and obese children and adolescents has significantly increased within the last 20 to 30 years, i.e. within only one generation, in nearly all industrial nations" (Lob-Corzilius, 2007:585). This is also the case for South Africa. In fact, the National Youth Risk Behaviour Study (YRBS) showed that $17 \%$ of high school children were overweight or obese (Reddy et al. 2003). The key causes of being overweight and obese were identified as, amongst others, changes in individual nutrition and physical activity behaviours. Daily physical activities and recreational activities have changed dramatically with the invention of new technologies such as televisions, personal computers and remote controls. Health consequences, such as metabolic syndrome, which is associated with insulin resistance, Type-2 diabetes, arterial hypertension and breathing difficulties, are expected to be worldwide concerns in the future (Lob-Corzilius, 2007:587).

According to Lob-Corzilius (2007:588), a review of the preventative programmes conducted by Summerbell et al. (2005) indicates that there is no substantial evidence of the success of intervention programmes aimed at preventing overweight children and adolescents; and, for currently obese children, these preventative programmes appear to have no impact on further course of obesity. Summerbell et al. (2005) cited by Lob-Corzilius (2007:588) highlighted the need for special education and training programmes for these children and showed that a school-centred approach was more successful. Some suggestions of aspects that should be included in these programmes include more mobility, active lifestyles, less sitting, and leisure and weekend activities (Lob-Corzilius, 2007:588)

\section{Hygiene}

"The community, or public, is composed of individuals, and it's only if each individual, i.e. if each member of community is healthy that a community can be healthy too" (De Haan, 1996:197). Poor standards of personal hygiene are associated with many conditions, such as pediculosis, scabies, trachoma, yaws and skin infections. "Not only does the individual whose standards of personal hygiene are poor endanger his own health but he also endangers the health of others, and many cases of infectious diseases may be traced to the poor hygiene habits of people who handle food or care for children "'(De Haan, 1996:197).

"Fresh air and sunlight are essential for psychological health and physical well being" (De Haan, 1996:200). Participants highlighted the problems of overcrowded classes: "Learners are congested in one class and when it's hot children complain of headache, nose bleeding and dizziness". This may be the result of the learners getting insufficient fresh air due to overcrowding. De Haan (1996:200) added: "Fresh air assists in cooling the skin, it stimulates circulation and improves ventilation of the lungs".

Studies evaluating interventions to promote personal and domestic hygiene, in addition to safe water and food practices, have documented improved health outcomes with improved hygiene practices (Nicolle, 2007:767). 'The psychosocial factors of children's environment doubtlessly constitute at the moment the most important pathogenic factor for children's well being and health" (Bose-O'Reilly, Heudorf, Lob-Corzilius, Muhlendahl, Otto \& Schmidt, 2007:506).

\section{Category 4 : Common health needs of learners}

In the fourth category, the following subcategories were identified: teenage pregnancy, family planning and HIV/ Aids.

\section{Teenage pregnancy}

The aspect of teenage pregnancy was raised as follows:

- "We have mostly problems with teenage pregnancy; their health needs are usually communicated to the Guidance teachers". "Well, teenage pregnancy is a national problem 
and it also goes hand in hand with HIV/Aids. But we as male teachers tend to shift this responsibility to lady teachers".

Pregnancy is a normal development process amongst women but has several impacts on the physical, social and psychological development of an adolescent child. Various clinics and schools provide services for teenagers in order to prevent unwanted pregnancies. In the social environment, all learners have the right to healthcare services and access to available health information from a school nurse and educators. It is vital that the government ensures that health and education services work jointly and effectively to limit the occurrence of teen pregnancy (Wikipedia, 2008). The Planned Parenthood Association of South Africa (PPASA) supports the above comments, and states that parents and their children have special needs and that these needs should be met to limit teenage pregnancy (PPASA, 2003:8). The PPASA (2003:23) continues to say that clinic services should be improved by providing assistance to pregnant teenagers by means of grants and equipping them with the necessary life skills to allow them to survive.

\section{Family planning}

The participants expressed the problems they faced with regard to family planning as follows:

"It is difficult to decide for the parents of the children. They must do what they think is right for their child". "We have never had a pregnancy in the school (special school) but I fear, when one observes how sexually ripe the boys are, I fear one day we will have a problem". "We teach learners during Life Orientation classes about family planning so that they can make informed decisions

According to IRIN News (2007), the number of pregnant girls has increased from 1169 in 2005 to 2336 in 2006 in Gauteng alone. This problem of teenage pregnancy has continued to grow despite the government's initiative of sex education and AIDS awareness. "South Africa has a huge teenage pregnancy problem - one in three girls has had a baby by the age of 20" (IRIN News, 2007). This problem was reiter- ated by the participants. These alarming rates of teenage pregnancy indicate low levels of contraceptive use. Contraceptives provide a safe and effective way to regulate fertility and preserve health (WHO, 1994). "Very" young, adolescent women who become pregnant face serious health risks because their bodies may not be physically mature enough to handle the stress of pregnancy" (WHO, 1994).

In addition to their effectiveness in preventing pregnancy, some contraceptives also have substantial non-contraceptive health benefits. "Contraceptive use reduces maternal mortality and improves women's health by preventing unwanted and high risk pregnancies and reducing the need of unsafe abortions" (WHO, 1994). Adults (particularly parents) have been identified as potential important sources of sexual health information but may withhold this information if they feel that sexual activity among young people is inappropriate or if they do not have the relevant information themselves. Family planning helps everyone; women, men, families, children, nations and the world (Hatcher, Rinehart, Blackburn, Geller \& Shelton, 1998:2-2).

\section{HIVIAIDS}

Participants' concerns regarding HIV/ Aids were expressed as follows:

"We have lots of rape cases and some victims are left HIV positive".

"A learner can come to me to tell that she is HIV positive but in no time you see her with this boyfriend, another and another in the same school. And as a Guidance teacher I have no right to warn the boyfriends about the HIV status or the risk". "I think we need guidance from outside or counselling; this problem traumatises us".

"South Africa and its neighbors lie at the epicenter of the HIV/AIDS epidemic and the resulting toll on human suffering in the region is immense" (Doherty \& Colvin, 2003:209). Estimates of the overall prevalence in South Africa indicate that between 4 and 6 million people are living with HIV/Aids. The prevalence rate among the youth, as given in the South African Health Systems Review, was found to be 9,3 per cent, with 12 per cent of women aged between 15 and 24 years being HIV positive (Doherty \& Colvin,
2003:199). One of the strategies of prevention, according to the HIV/Aids/ STD Strategic Plan for 2000 to 2005 (HIV/AIDS/STD Strategic plan for South Africa 200-2005.Pretoria: National Department of Health; 2000), was to implement life skills in all primary and secondary schools. According to this strategic plan, the youth are a specific focus area in the fight against HIV/ Aids, as people between the ages of 14 and 35 years are the most vulnerable to $\mathrm{HIV}$ infection. It is important that the youth are targeted in order to protect them against future HIV infections, as they represent both the present and future economic powerhouse of the country (HIV/AIDS/STD Strategic plan for South Africa 200-2005. Pretoria: $\mathrm{Na}$ tional Department of Health; 2000).

\section{Sexually transmitted diseases}

The participants expressed the problem of sexually transmitted diseases (STDs) or sexually transmitted infections (STIs) as follows:

"We have very poor collaboration with the local clinic nurses. We only, get nurses from the University". "I don't even know' the different types of STIs".

"Learners do not talk when they have contracted STIs".

A lack of knowledge about STDs, poor support structures and the stigmatisation of people with STDs were highlighted as problems by the participants. The WHO estimates that every year more than 340 million new cases of the common bacterial and protozoal STIs, such as syphilis, gonorrhoea, chlamydial genital infections and trichomoniasis, occur throughout the world in men and women aged between 15 and 49 years (WHO, 2006). "STIs present a major disease burden for South Africa as well as many other developing countries. Sexually transmitted infections may be present without symptoms or with symptoms that are mild and transient, but they may have long term consequences such as infertility, ectopic pregnancy, chronic illness and premature death" (WHO, 2006).

The prevention, management and control of STIs is one of the priority areas of the national HIV/Aids/STD Strategic Plan for 2000 to 2005 (South African Health Review 2002-2003, 
2003:230). According to a national STI control programme, prevention of new STIs, including HIV, can be achieved by behaviour change campaigns, as well as one-on-one health education and counselling to promote healthy sexual lifestyles and risk reduction through delayed onset of sexual activity, abstinence and correct condom use. Control of STIs is however blocked by, amongst other factors, ignorance and lack of information that perpetuate misconceptions and associated stigmatisation (WHO, 2006). Varga and Shongwe, 1999:13) identify the reasons behind the failure of school-based reproductive health and life skills education efforts in the KwaZulu-Natal region as division and unequal resource allocation, lack of system-level support for schools, and inadequate preparation and training of educators.

\section{Unique needs of special learners}

The problems and health needs of special learners faced by participants at school were highlighted as follows:

"The problem that I see as urgent is the bigger children who start to masturbate, especially the boys". "They embarrass us when they start masturbating in public". "When the girls start to menstruate, it is a big problem because they cannot look after their hygiene". "We provide them with sanitary pads but their mothers are too poor to even buy them proper pads".

Special education needs arise from children's disabilities or learning difficulties. A study conducted by Engelbrecht, Swart and Eloff (2003) and discussed by Kibel \& Wagstaff, 1995:210) identified "sustaining an active learning environment for the learners with intellectual disability" as one of the most stressful issues for educators and concluded: "The school health team may need to be assisted by multidisciplinary academic hospitals teams, psychological and educational teams". Lehr and Noonan (1989:141) stated: "Students with complex health care needs are generally not ill, but require some health services to participate in special education".

\section{Category 5: Indirect health problems}

Within the fifth category, four subcategories were identified, namely: poverty, poor family structure, lack of resources and need for a health team.

\section{Poverty}

The participants expressed that:

- $\quad$ "Poverty is regarded as a health problem".

- "Poverty is a major problem, we do not know how to alleviate it in our school. We have a vegetable garden, but it is not enough to supply all the needy learners".

- "I think some girls get pregnant just to be able to access the grant".

Poverty is a social problem that is inherent in many communities irrespective of whether they are rural or urban. Many rural communities are vulnerable to being poor because of lack of resources and accessible information. Gyekye and Akinboade (2001:15) assert that developmental programmes in rural communities should be intensified where people are poor. The authors further add that any strategy of poverty alleviation should pay attention to increasing the skills of people who are poor in order to enable them to control their poverty status. Many people are poor not because they lack resources, but because they do not have the relevant information on how to manage poverty. Therefore, there is a need to empower communities to control their lifestyles.

\section{Poor family structure}

Families have structures that are difficult to recognise. During the discussions, the participants mentioned that: "We are having a growing number of orphaned learners, a child who is still a minor, mavbe 15 to 16 years old, must act as parent to younger brothers and sisters at home". "Some kids stav alone for the whole month as parents work far and come only at month end". "Most of the kids live with the grandparents and they don't have a strong hold over the children".

The family unit is comprised of different structures. These structures contribute to the survival of the whole family. If one structure of the family is affected, the whole family will be affected (Friedman, Bowden \& Jones 2003:154).
If the family is poorly structured, the family members will experience various health and social problems. Poor family structure may have an impact on the school performance of children. It was found that children from father-absent homes manifest a number of internalising and externalising behaviours such as sadness and aggression (Jamaica Gleaner, 2006). These behaviours impact on the performance of the child. It should be noted that proper assessment should be done when a child enters the school environment to rule out any health, social and psychological problems.

\section{Lack of resources}

Lack of resources remained a topic of focus for the participants

"Need for sports facilities". "We need better sports grounds and facilities to take the learners' minds away from sex".

Available resources ease strategies and activities directed to helping the communities. They contribute toward a feeling of self-reliance and self-sufficiency. Lack of facilities may hamper progress in any situation. The National Indian Educational Association (2002:1) in Washington states that children should be provided with resources in order to help them to succeed in their school performance. Carr (2004) adds that lack of resources hampers school information. Therefore, there is a need for school resources, such as school web information, to ensure the smooth running of school activities.

\section{Need for full health team}

The participants emphasised the need for a full medical team as follows:

"We need and plead that the University of Pretoria should bring an effective team which will look at the physical, mental, social and economic problems, not only for Mankala High School but the whole district of Makapanstad".

A full health team implies a multidisciplinary team that will cater for the learners, educators and community from a holistic care approach. The multidisciplinary approach is vital in meeting the needs of clients and of care providers (Hattingh, Dreyer and Roos, 2006:95). To attain satisfaction in health promoting schools, all stakeholders 
should share ideas and reach consensus. Hattingh et al, (2006:218) add that in a multidisciplinary team approach, members share responsibilities, talents, knowledge, functions, expertise, experience, ideas and proposals.

Both professionals and non-professionals need to come together to establish a healthy and well-functioning multidisciplinary team that can address health issues affecting the health of learners and educators. In the School Health Policy and Implementation Guidelines (South Africa, Department of Health, 2003:10), one of the objectives stipulated is that the school community should be assisted through the development of intersectoral plans to support and develop health promoting schools.

\section{Limitation of the study}

The study was limited only to the educators who are working in the four schools in Makapanstad community therefore the results cannot be generalised to other communities. In addition, availability of teachers during data collection remained a barrier because the researcher had to wait for these teachers to participate in the research project because at the same time teachers had to be responsible in their teaching.

\section{Conclusion}

The methodology guided the researchers during the research process and relevant information was obtained from Makapanstad educators. The health education training needs of educators at Makapanstad schools were explored, described and theoretically confirmed. Data were analysed using the Tesch analysis process. Categories and subcategories were identified and scientifically controlled. The focus of the categories was the need for the support of the University for the training of educators, the need for the acknowledgement of the University for educators' responsibility, the need for basic knowledge on health promotion, common health needs of learners and indirect health problems. The subcategories identified form the basis of a health education programme for educators in Makapanstad schools. The investigation assisted in the improvement of collaboration between the University of Pretoria and Makapanstad schools. This is important, as Makapanstad is a rural area that needs attention from an academic institution.

\section{Recommendations}

With reference to the analysed data and the School Health Policy and implementation Guideline (2003: 4, 9 and 10) and Uganda National Health Policy (2009) the following recommendations were made:

- The development and validation of a health education package that will assist educators to empower learners.

- The establishment and monitoring of a poverty relief programme for all learners.

- The encouragement and sustainability of a proper health promoting school programme for all schools.

- The assessment of individual learners for the purposes of identifying any hampering situations earlier and facilitating the earlier referral of learners to healthcare professionals.

- The provision of resources to the schools in order to ensure the smooth running of school

- Educators should have both the sole and joint responsibility to ensure a safe environment for learners.

\section{References}

BOSE-O'REILLY, S; HEUDORF, U; LOB-CORZILIUS, T; MUHLENDAHL, K; OTTO, M \& SCHMIDT, S 2007: Children's environment in Central Europe: Threats and chances. International Joumal of Hygiene and Environmental Health. 210(5):503-7.

BOYLE, MA 2003: Community nutrition in action. $3^{\text {rd }}$ Edition. USA: Thompson and Wordsworth.

BRINK, HI 1999: Fundamentals of research methodology for health care professionals. Cape Town:Juta.

CARR, N 2004: Lack of resources hampers school web site [online]. Available: http://www.eschoolnews.com/news/ top-news/index.cfm? $\mathrm{i}=36045 \& \mathrm{CFI} \mathrm{D}=$
771720\&C.... [Accessed: 13 March 2008].

CRESWELL, JW 2003: Research design: Qualitative and quantitative approaches. California: Thousand Oaks.

DE HAAN, M 1996: The health of Southern Africa. $7^{\text {th }}$ ed. Kenwyn: Juta.

DE VOS, AS; STRYDOM, H; FOUCHÉ, CB \& DELPORT, CSL 2002: Research at grass roots. Pretoria: Van Schaik.

DOHERTY, T \& COLVIN, M 2003: HIV/Aids. South African Health Systems Review. 2002-2003 [online]. South Africa: Health System Trust. Available: http//www.hst.org.za/publications/527. [Accessed: 4 June 2007].

DRAKE, L; MAIER, C; JUKES, M; PATRIKIOS, A; BUNDY, DAP; GARNER, A \& DOLAN C 2002: Schoolage children: SCN News, 25: p4-30.

EDELMAN, CL \& MANDLE, E 2002: Health promotion: Throughout the lifespan. $5^{\text {th }}$ ed. St. Louis: Mosby.

ENGLAND DEPARTMENT FOR EDUCATIONAND EMPLOYMENT, 1998: Health and safety of pupils on educational visits. London: Department for Education and Employment.

FRIEDMAN, MM; BOWDEN, VR \& JONES, EG 2003: Family nursing: Research, theory and practice. $5^{\text {th }}$ ed. New Jersey: Prentice Hall.

GUBA, EG 1981: Criteria for assessing the trustworthiness of naturalistic inquiries. Educational Resources Information Centre Annual Review Paper, 29:75-91.

GYEKYE, AB \& AKINBOADE, OA 2001: Analysis of poverty in the Northern Province of South Africa: Implications for empowerment policy. Pretoria: University of South Africa.

HATCHER, R; RINEHART, W; BLACKBURN, R; GELLER, J \& SHELTON, J 1998: The essentials of contraceptive technology. Baltimore: Population Information Program, Center for Communication Programs, The Johns Hopkins School of Public Health.

HATTINGH,S; DREYER, M \& ROOS, 
S 2006: Aspects of Community Health. Cape Town: Oxford University Press.

HIV/AIDS/STD STRATEGIC PLAN FOR SOUTH AFRICA 20002005.PRETORIA: National Department of Health; 2000 URL: http// www.doh.gov.za/docs/policy/aidsplan00-05.pdf

IRIN NEWS 2007: Teenage pregnancy figures cause alarm [online]. Available: http//www.IRINnews.org. [Accessed: 12 March 2007].

JAMAICA GLEANER 2006: Impact of family structure on children [online]. Available: http://www.jamaicagleaner.com/gleaner/20060416/focus/ focus 2.html. [Accessed: $13 \mathrm{March}$ 2007].

KATZENELLENBOGEN, JM, JOUBERT, G\& KARIM, A 1997: Epidemiology: A manual for South Africa. Cape Town: Oxford University Press.

KIBEL, W \& WAGSTAFF, LA 1995: Child Health for all: A manual for South Africa. $2^{\text {nd }}$ Edition. Oxford University press. South Africa.

LEHR, DH \& NOONAN, MJ 1989: Issues in the education of students with complex health care needs: Persons with profound disabilities, issues and practices. Baltimore: Paul $\mathrm{H}$ Brookes Publishing.

LEURS, MTW; BESSEMS, K; SCHAALMA, HP \& DE VRIES, H 2007: Focus points for school health promotion improvements in Dutch primary schools. Health Education Research. 22(1):58-69.

LINCOLN, YS \& GUBA, EG 1985: Naturalistic inquirv. London: Sage.

LOB-CORZILIUS, T 2007: Overweight and obesity in childhood: A special challenge for public health. International Journal of Hvgiene and Environmental Health. 210(5):585-9.

LUNDY, KS \& JANES, S 2001: Community health nursing: Caring for the public's health. London: Jones and Bartlett.

MEYERS, DG 2007: Intuition: Its powers and perils [online]. Available: http:/ Iwww.davidmevers.org
Brix?pageID=84). [Accessed: 17 March 2008].

NATIONALINDLANEDUCATIONAL ASSOCIATION. 2002. Funding Indian education through impact. Washington: National Indian Educational Association.

NEEDS ASSESSMENT REPORT. HEALTH PROMOTINGSCHOOLS' PROJECT IN MAKAPANSTAD. 2004: University of Pretoria, School of Healthcare Sciences, Faculty of Health Sciences. (Unpublished report.)

NICOLLE, L 2007: Hygiene: What and why. Canadian Medical Association Journal. 176(6):767-8.

PIPES, PL \& TRAHMS, CM 1993: Nutrition in infancy and childhood. $5^{\text {th }}$ ed. St Louis: Mosby.

POLIT, DF \& HUNGLER, BP 1997: Nursing research: Principles and methods. Philadelphia: Lippincott.

PPSA 2003: See Planned Parenthood Association of South Africa. 2003.

REDDY, SP; PANDAY, S; SWART, D; JINABHAI, CC; AMOSUN, SL; JAMES, S; MONYEKI, KD; STEVENS, G; MOREJELE, N; KAMBARAN, NS; OMARDIEN, RG; VAN DEN BORNE, HW. 2003: Umthenthe Uhlaba Usamila - The South African Youth Risk Behaviour Survey 2002. Cape Town, South Africa Medical Research Council.

REES, J \& KANABAR, D 2000: ABC of asthma. $4^{\text {th }}$ Edition.$B M J$ books.London.

\section{SOUTHAFRICADEPARTMENT OF}

HEALTH. 2003: School Health Policy and Implementation Guidelines. Pretoria: Government Printers.

\section{SOUTH AFRICADEPARTMENT OF}

HEALTH 2001: Policy Guidelines for Youth and Adolescents' Health. Pretoria: Government Printers.

\section{SOUTHAFRICANHEALTHREVIEW} 2002-2003 [ONLINE]. 2003: South Africa: Health System Trust. Available: http//www.hst.org.za/publications/527. [Accessed: 4 June 2007].
STANHOPE, M \& LANCASTER, J 2000: Community public health nursing. St Louis: Mosby.

STEYN, NP; BRADSHAW, D; NORMAN, R; JOUBERT, J; SCHNEIDER, M \& STEYN, K 2006: Dietary Changes and the Health Transition in South Africa: Implications for Health Policy. Cape Town, Chronic Diseases of Lifestyle Unit and Burden of Disease Research Unit of the Medical Research Council.

UGANDA NATIONAL HEALTH POLICY 2009: Reducing poverty through promoting people's health. Uganda: Government Printers.

UNUSAN, N \& SANLIER, N 2007: A Turkish perspective on nutrition, education and pre-school children. Early Childhood Development and Care. 177(8):853-62.

VARGA, C \& SHONGWE, B 1999: School based reproductive health education. Health System Trust. South Africa

WENHOLD, F; KRUGER S \& MUELHOF E 2008: Nutrition for school-age children and adolescents. In: Steyn N \& Temple N. Community nutrition textbook for South Africa: A rights-based approach. Tygerberg. Chronic Diseases of Lifestyle Unit of the South African Medical Research Council.

WIKIPEDIA 2008: Teenage pregnancy. (Online: http://en.wikipedia.org/ wiki/Teenage-pregnany)

[Accessed: 01/08/2008]

WORLD HEALTH ORGANIZATION 2006: Prevention and control of sexually transmitted infections: Global strategy [online]. Available: http// www.who.int/reproductive-health/stis/ docs/stiskeymsgs.pdf. [Accessed: 22 May 2007].

WORLD HEALTH ORGANIZATION 1994: Health benefits of family planning. Family planning and population division of family health. [Online: http/ /www.who.int/reproductive-health/ publication/health benefits famil $\quad \eta$ ning [Accessed:22 May 2007]. 